\title{
Treatment of Effluents Containing High Total Dissolved Solids By Multi-Effect Evaporator
}

\author{
Sareddy Ravi Sankara Reddy, Manoj Kumar Karnena, Bhavya Kavitha Dwarapureddi and Vara Saritha $\uparrow$ \\ Department of Environmental Science, GITAM Institute of Sciences, GITAM (Deemed to be) University, Visakhapat- \\ nam, Andhra Pradesh, India \\ †Corresponding author: Vara Saritha; vsjr08@gmail.com
}

\section{Nat. Env. \& Poll. Tech. Website: www.neptjournal.com \\ Received: 08-10-2019 \\ Revised: 12-11-2019 \\ Accepted: 11-12-2019}

\section{Key Words:}

Multi-effect evaporator

Pharmaceutical waste

Effluent treatment

Total dissolved solids

\begin{abstract}
Pharmaceutical effluent disposal is a serious problem in the present times. The manufacturing process involves the use of both organic and inorganic compounds, which contribute to high chemical oxygen demand and dissolved solids. The common techniques used to extract available salts and to produce reusable waters are evaporation and cooling. Evaporators are equipment used for evaporation which is a kind of heat transfer system in which transfer mechanism is controlled by natural or forced convection. Multi-effect evaporators in many industries are used for volume reduction and cutting down the waste handling cost. This paper focusses on studying the efficiency of multi-effect evaporators in the pharmaceutical industry for the treatment of high total dissolved solids (HTDS) waste streams. The feed and condensate parameters were monitored for three years. Competence of the treatment process is presented in terms of reduction in TDS and COD. The current study evaluates the efficiency of MEE in terms of removal of total dissolved solids and chemical oxygen demand. Removal efficiencies are more than $98 \%$ for TDS and $50 \%$ for COD.
\end{abstract}

\section{INTRODUCTION}

Evaporation is understood as vaporization of liquid or solvent from a solution. The objective of evaporation is to concentrate solution. Evaporators are equipment used for evaporation which is kind of heat transfer systems in which transfer mechanism is controlled by natural or forced convection. The process of evaporation includes feeding of solution and heating with a heat source like steam leading to the conversion of water in the solution to vapour which is condensed while the solution that got concentrated is removed for further processing.

Use of single evaporator is called single effect evaporator system while the use of more than one evaporator is termed as the multiple-effect evaporator system (Hanamapure et al. 2016). Addition of each effect increases the steam economy of the system. Evaporation is the most energy-intensive process in an industrial operation, hence, many researchers have focussed on the processes to shrink consumption of energy to make the process cost-effective. Operating strategies employed include compression and bleeding of vapour, feed, condensate and product flashing, and feed and steam splitting.

Evaporators, precisely multi-effect evaporators, have become an integral part of many processes in wide industries including sugar, paper and pulp, dairy, desalination, food processing and pharmaceuticals, etc. (Shah \& Bhagchandanc 2012, Sarma \& Barma 2010, Kumar et al. 2013, Kumar et al. 2010, Zain \& Kumar 1996, Danish \& Sachin Pratap 2014, Bhargava et al. 2008). Multi-effect evaporators yield high value of the coefficient of performance in comparison to a single effect evaporator system. Fluctuations in load are controlled easily by controlling individual evaporator. Further, lesser space and initial cost are additional advantages of single compressor multi-evaporator systems.

Multi-effect evaporators in many industries are used for volume reduction and cutting down of waste handling cost (Bhargava et al. 2008). In distillery units, spent wash is subjected to volume reduction through multi-effect evaporator or reverse osmosis (Apte 2012). Black liquor is one of the voluminous and critical pollutant streams from paper and pulp industry processes which contains solids between 12 to $20 \%$. The concentration of this stream to nearly $50 \%$ is carried out in multi-effect evaporator using low-pressure steam, where vapour from one evaporator is supplied as steam for the next evaporator resulting in a high steam economy (Deepak Kumar et al. 2010).

Application of evaporation in the pharmaceutical industry is two-fold. First, in the manufacturing process, evaporation is used to eliminate excess moisture from pharmaceutical products which improves the stability of the product enabling 
its easy handling. Further, evaporation aids in preserving long-term activity and stabilization of enzymes. Second, evaporation of wastewaters from the manufacturing process of the pharmaceutical industry is carried out using multi-effect evaporators which will reduce the volume and separate solvents from the effluents. $99 \%$ reduction in total dissolved solids and $90 \%$ reduction in total organic carbon for various industrial wastewaters was achieved upon treatment with multi-effect evaporator. Highest removal of total organic carbon was seen in pharmaceutical wastewaters.

Leakages and scales are common problems associated with evaporators, overcoming these problems will result in enhancing the efficiency of multi-effect evaporators as reported by Salakki et al. (2014). Their evaluation presented $91.5 \%$ and $96 \%$ exclusion of chemical oxygen demand and total dissolved solids respectively. Further, the pharmaceutical industry has adopted multiple-effect (falling and forced circulation) evaporator towards achieving zero liquid discharge (Gupta et al. 2018). Studies on bulk drug industry showed that effluent treatment is carried out by multi-effect evaporators for waste streams containing high total dissolved solids followed by biological treatment (Vuppala et al. 2012). $98 \%$ reduction in COD and TDS was reported by Salakki et al. 2014 when pharmaceutical effluent was treated in the multi-effect evaporator.

This paper focusses on studying the efficiency of multi-effect evaporators in the pharmaceutical industry for the treatment of high total dissolved solids (HTDS) waste streams. Competence of the treatment process is presented in terms of reduction in TDS and COD.

\section{MATERIALS AND METHODS}

Flowchart of methodology for the treatment system for multiple-effect evaporation to remove dissolved solids from the pharmaceutical industry is shown in Fig. 1.

\section{Study Area}

The present study has been carried out at MSN Laboratories Private Limited, a research-based pharmaceutical company in Hyderabad, Andhra Pradesh, India.

\section{Sample Collection}

Water samples from MEE feed condensate and concentrate were collected every day with a temporal frequency of morning, afternoon and evening, and the composite sample was made from the three samples. Samples were collected in sterile plastic containers and transferred instantly to the laboratory in the premises of the industry. The analysis was taken up immediately and completed within 48 hours. Samples were stored at $4{ }^{\circ} \mathrm{C}$ for analysis during the following days.

\section{Physico-Chemical Analysis}

Total of 24 physico-chemical parameters was analysed as per the standards methods (APHA 2012). All the parameters were analysed in triplicate to avoid errors.

\section{RESULTS}

Table 1 presents the treatment of process effluents using Multiple Evaporators represents focussing on three parameters $\mathrm{pH}$, TDS and COD. Table 1 presents the ten-month

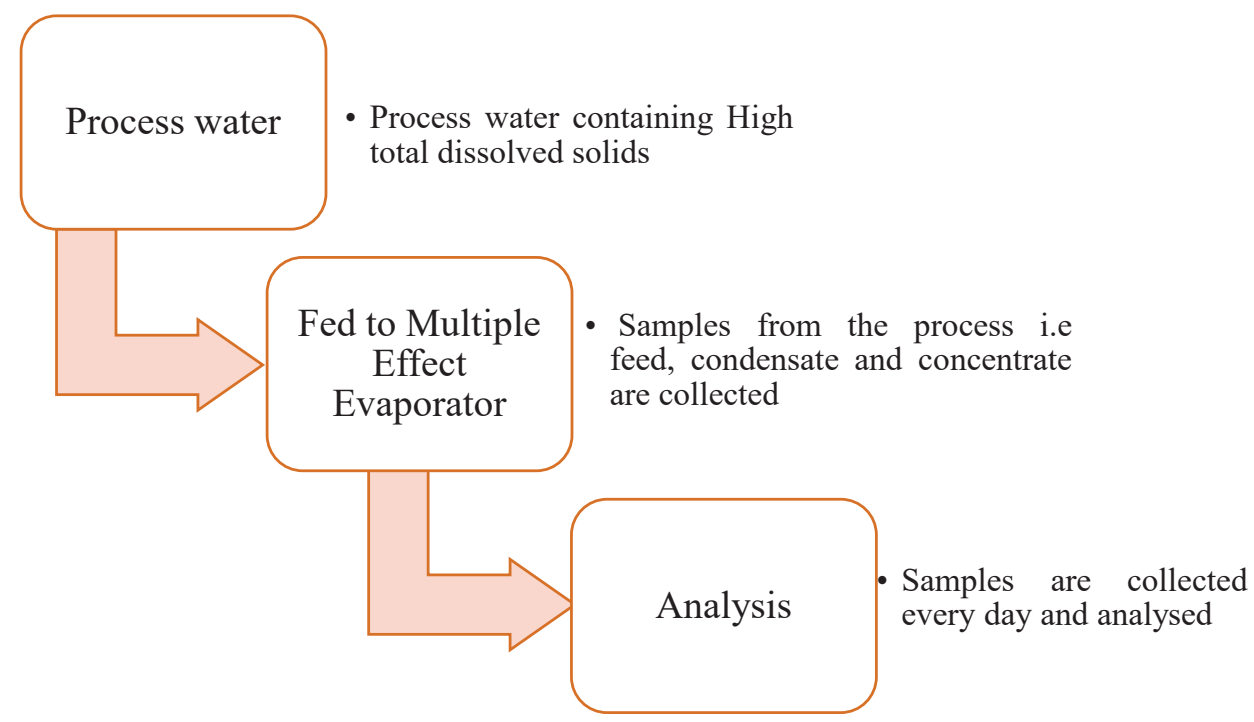

Fig. 1: Flowchart of methodology. 
data of MEE treatment with details of feed, condensate and concentrates for the year 2018.

$\mathrm{pH}$ trend for MEE feed was found to be lowest and highest during January and August, i.e. 6.69 and 7.20. Lowest and highest values for TDS were $32867.74 \mathrm{mg} / \mathrm{L}$ and 41605.00 $\mathrm{mg} / \mathrm{L}$ during January and June. Further, the lowest and highest values for COD were observed to be $47200.00 \mathrm{mg} / \mathrm{L}$ and $56506.67 \mathrm{mg} / \mathrm{L}$ in January and October.

With reference to MEE condensate $\mathrm{pH}$ trend was observed to be lowest (7.83) during January and highest of 8.55 in September. Lowest and highest values for TDS were $373.23 \mathrm{mg} / \mathrm{L}$ and $506.00 \mathrm{mg} / \mathrm{L}$ during January and October. Further, the lowest and highest values for COD were observed to be $19483.87 \mathrm{mg} / \mathrm{L}$ and $23973.33 \mathrm{mg} / \mathrm{L}$ in January and October.
$\mathrm{pH}$ variations for MEE concentrate were noted as 5.75 being lowest and 6.00 being highest reported during January and April respectively. Similarly, the lowest and highest values for TDS were recorded to be $191390.32 \mathrm{mg} / \mathrm{L}$ and $205580.00 \mathrm{mg} / \mathrm{L}$ in January and September. Regarding COD, $139933.55 \mathrm{mg} / \mathrm{L}$ and $172960.00 \mathrm{mg} / \mathrm{L}$ were the least and highest values obtained during January and October respectively.

Table 2 presents the percentage reduction in TDS and COD during the study after treatment with multiple effect evaporators. Maximum average percentage reduction of TDS was observed to be $98.77 \%$ and COD of $58.26 \%$.

\section{DISCUSSION}

Term multi-effect evaporators originate from multiple ef-

Table 1: Treatment of process effluents using Multiple Effect Evaporators (MEE).

\begin{tabular}{|c|c|c|c|c|c|c|c|c|c|}
\hline \multirow{2}{*}{ Months } & \multicolumn{3}{|c|}{ Stripper / MEE Feed } & \multicolumn{3}{|c|}{ MEE Condensate } & \multicolumn{3}{|c|}{ MEE Concentrate/Atfd Feed } \\
\hline & $\mathrm{pH}$ & TDS (mg/L) & $\mathrm{COD}(\mathrm{mg} / \mathrm{L})$ & $\mathrm{pH}$ & TDS (mg/L) & $\mathrm{COD}(\mathrm{mg} / \mathrm{L})$ & $\mathrm{pH}$ & TDS (mg/L) & $\mathrm{COD}(\mathrm{mg} / \mathrm{L})$ \\
\hline January & 6.69 & 32867.74 & 47200.00 & 7.83 & 373.23 & 19483.87 & 5.75 & 191390.32 & 139933.55 \\
\hline February & 7.03 & 33532.14 & 53142.86 & 8.18 & 420.71 & 22314.29 & 5.83 & 204089.29 & 145314.29 \\
\hline March & 6.99 & 35393.55 & 50829.03 & 8.24 & 400.97 & 20903.23 & 5.88 & 197154.84 & 151696.77 \\
\hline April & 7.03 & 38604.33 & 53306.67 & 8.23 & 422.00 & 22186.67 & 6.00 & 206376.67 & 159906.67 \\
\hline May & 7.00 & 36743.33 & 51600.00 & 8.46 & 417.00 & 21293.33 & 5.90 & 203676.67 & 154293.33 \\
\hline June & 6.77 & 41605.00 & 53013.33 & 7.99 & 461.67 & 21693.33 & 5.60 & 200906.67 & 164880.00 \\
\hline July & 7.06 & 37219.35 & 54890.32 & 8.40 & 462.58 & 22941.94 & 5.63 & 202600.00 & 166916.13 \\
\hline August & 7.20 & 35125.81 & 52670.97 & 8.34 & 455.16 & 22277.42 & 5.88 & 200680.65 & 165845.16 \\
\hline September & 7.14 & 34580.00 & 54026.67 & 8.55 & 488.33 & 23053.33 & 5.83 & 205580.00 & 172746.67 \\
\hline October & 7.08 & 34240.00 & 56506.67 & 8.50 & 506.00 & 23973.33 & 5.90 & 202833.33 & 172960.00 \\
\hline
\end{tabular}

Table 2: TDS and COD removal in percentage (\%).

\begin{tabular}{|lll|}
\hline Months & TDS & COD \\
\hline January & 98.86 & 58.72 \\
February & 98.75 & 58.01 \\
March & 98.87 & 58.88 \\
April & 98.91 & 58.38 \\
May & 98.87 & 58.73 \\
June & 98.89 & 59.08 \\
July & 98.76 & 58.20 \\
August & 98.70 & 57.70 \\
September & 98.59 & 57.33 \\
October & 98.52 & 57.57 \\
November & - & - \\
December & - & - \\
Avg $(\%)$ & 98.77 & 58.26 \\
\hline
\end{tabular}


fective use of energy in performing the task of evaporation. Under this configuration, condensation of live steam takes in the first effect evaporator only, vapours produced are sent to condense in the next or second effect evaporator for further evaporation. This process is repeated until the last evaporator is reached where condensation of the produced vapours takes place in a condenser equipped with cooling water (Bremford \& Muller-Steinhagen 1994, Konopa 1997). Foremost mention of the multiple-effect evaporator (MEE) was dated during 1840, regarding one of the oldest and widely adopted desalination process in the world (Al-Mutaz 2015).

Adopted widely for seawater desalination (El-Dessouky et al. 1999), MEE, with its applications, has also become an integral part of many industrial processes including dairy, petrochemicals, pulp and paper and food processing. Among others, one of the advantages of MEE is the reduction in the cost of handling waste by reducing the volume of the waste (Bhargava et al. 2008). Many workers have studied mathematical and nonlinear mathematical modelling approaches for MEE (El-Dessouky and Ettouney, 2002, Yılmaz \& Söylemez 2012, Gautami \& Khanam 2012, Druetta et al. 2013, El-Dessouky et al. 2000, Ettouney 2006) with regard to energy efficiency. EI-Dessouky et al. (2000), presented various models for MEE systems design for seawater desalination. However, the point to be noted is that these works were only regarding seawater desalination. Hence, it is understood that these studies have not made any consideration regarding the treatment of various industrial effluents to reduce the volume and other applications.

Treatment of pharmaceutical effluents using MEE in the present study has resulted in a significant reduction in total dissolved solids (99\%) and chemical oxygen demand (88.32\%). The study carried out by Srikanth et al. (2012) in a bulk drug industry reported that wastewater streams having HTDS were treated using MEE, where these wastewaters were initially sent through a steam stripper which was followed by MEE and then to agitated thin film drier (AFTD). The similar process has been adopted in the treatment of wastewaters in the present study. Chow et al. (2001) reported lesser steam requirement ( $3655 \mathrm{~kg}$ ) for treating $25 \mathrm{KL}$ effluent in MEE after a detailed study on the operating conditions in treating pharmaceutical industry wastewaters. When wastewater with high TDS was treated in MEE, 99\% recovery of water was stated by Matkar et al. (2017). The input quantity was $30 \mathrm{KLD}$ while $27 \mathrm{KLD}$ was recovered.

Salakki et al. (2014) evaluated the performance of MEE for treatment of pharmaceutical industry and stated that they obtained $91.5 \%$ reduction in chemical oxygen demand, while the reduction in total dissolved solids was $96 \%$. Apte \& Hivarekar (2014) have quoted technique of multi-effect evaporation to be an efficient alternative towards achieving volume reduction of up to $75 \%$ while studying the treatment options for distilleries. Further, they stated that if the condensate can be treated properly, it can be utilized as a source of raw water. Reduction of COD from $2000 \mathrm{mg} / \mathrm{L}$ to $60-240$ $\mathrm{mg} / \mathrm{L}$ was obtained when textile wastewaters were prone to treatment with evaporation followed by reverse osmosis.

From the above discussion of the previous studies regarding efficiency of MEE treatment, this process is considered to be highly attractive for its design and operating features making it both competitive and applicable for several industries and processes. Features that make MEE competitive as per the previous and present study are:

1. Process configuration of MEE permits simple alterations for routing and distributing wastewater streams among the effects of the system (El-Dessouky et al. 1998, El-Dessouky et al. 2000).

2. Capital investment of MEE is considered to be low in comparison to other processes owing to its lesser number of effects, partition walls and tube connections (Morin 1993, Wade 1993, Hamed et al. 2004, El-Dessouky et al. 2000).

3. Operation load stability of MEE is observed over a range of $30 \%$ to $120 \%$ of its design capacity (El-Dessouky et al. 1995, Darwish et al. 1996, Fritzmann et al. 2007, Greenlee et al. 2009, Al-Bastaki et al. 1999). This feature is attributed to less feed to product ratio permitting larger variation in the operating conditions of the system.

Rukade \& Bhosale (2014) opined that if MEE and RO were to be incorporated in the treatment design as alternatives for the technology of volume reduction primarily, then such systems may be promising and provide a benchmark database reducing costs and area requirements. Further, these may add to the notion of zero discharge. Previous studies stated that one of the major aspects of zero liquid discharge plant is having multiple-effect evaporator as one of the treatment options which can save $50 \%$ of water per day, which is a large amount that can be utilized for other purposes (Hareesh 2017).

\section{CONCLUSIONS}

Results of physico-chemical characteristics of pharmaceutical wastewaters reveal thorough or higher degree treatment of high total dissolved solids stream which initially starts with feeding this stream to multiple-effect evaporator. The study on the efficiency of MEE is evaluated in terms of removal of total dissolved solids and chemical oxygen demand. Removal efficiencies are as follows: 
- Reduction in total dissolved solids was more than $98 \%$ during the entire study period, the maximum average percentage reduction of TDS was observed to be 98.77 $\%$.

- Reduction in chemical oxygen demand was above $50 \%$ during the study period, maximum average percentage reduction of COD was observed to be $58.26 \%$.

\section{REFERENCES}

Al-Bastaki, N.M. and Abbas, A. 1999. Modeling an industrial reverse osmosis unit. Desalination, 126(1-3): 33-39.

Al-Mutaz, I. S. and Wazeer, I. 2014. Comparative performance evaluation of conventional multi-effect evaporation desalination processes. Appl. Therm. Eng., 73(1): 1194-1203.

Apte, S. 2012. Anaerobic Filter for Distillery Condensate Treatment. Lap Lambert Academic Publ.

Bhargava, R., Khanam, S., Mohanty, B. and Ray, A.K. 2008. Simulation of flat falling film evaporator system for concentration of black liquor. Comput. Aided Chem. Eng., 32(12): 3213-3223.

Bremford, D. J. and Müller-Steinhagen, H. M. 1994. Multiple effect evaporator performance for black liquor. Part 1: Simulation of steady state operation for different evaporator arrangements. Appita J., 47(4): 320-326.

Chow, C., Anand, A.K., Ranasinghe, J. and Stats, D.A. 2001. U.S. Patent No. 6,170,263. Washington, DC: U.S. Patent and Trademark Office.

Danish, M. and Singh, S.P. 2014. A short note on the solution of a multi-effect evaporator system employed in pulp and paper industry. Appl. Math. Model., 38(15-16): 4157-4160.

Darwish, S., Riad, A.S. and Soliman, H.S. 1996. Electrical conductivity and the effect of temperature on photoconduction of $n-\mathrm{ZnSe} / \mathrm{p}-\mathrm{Si}$ rectifying heterojunction cells. Semicond. Sci. Tech., 11(1): 96.

Druetta, P., Aguirre, P. and Mussati, S. 2013. Optimization of multi-effect evaporation desalination plants. Desalination, 311: 1-15.

El-Dessouky, H.T. and Ettouney, H.M. 1999. Multiple-effect evaporation desalination systems. Thermal Analysis. Desalination, 125(1-3): 259-276.

El-Dessouky, H. T., Ettouney, H. M. and Al-Juwayhel, F. 2000. Multiple effect evaporation-Vapour compression desalination processes. Chem. Eng. Res. Des., 676-662:(4)78.

El-Dessouky, H.T. and Ettouney, H.M. 2002. Fundamentals of Salt Water Desalination. Elsevier.

Ettouney, H. 2006. Design of single-effect mechanical vapor compression. Desalination, 190(1-3): 1-15.

Fritzmann, C., Löwenberg, J., Wintgens, T. and Melin, T. 2007. State-ofthe-art of reverse osmosis desalination. Desalination, 216(1-3): 1-76.

Gautami, G. and Khanam, S. 2012. Selection of optimum configuration for multiple effect evaporator system. Desalination, 288: 16-23.
Greenlee, L. F., Lawler, D. F., Freeman, B. D., Marrot, B. and Moulin, P. 2009. Reverse osmosis desalination: Water sources, technology, and today's challenges. Water Res., 43(9): 2317-2348.

Gupta, S. K., Shin, H., Han, D., Hur, H. G. and Unno, T. 2018. Metagenomic analysis reveals the prevalence and persistence of antibiotic-and heavy metal-resistance genes in wastewater treatment plant. J. Microbiol., 415-408:(6)56.

Hanamapure, N. S., Saini, D. R. and Pharande, M. S. A. 2016. Optimization of parameters of multi effect evaporator used in the design for the dye industry. Int. J. Sci., 2(10): 1056-1059.

Hareesh, G., Arun, S. and Shanmugam, D. P. 2017. Comparative analysis of multiple effect evaporators and anaerobic digester (UASB) for an effective management of RO reject from tannery. Int. J. Civ. Eng., 8(4): 809-815.

Konopa, J. P. 1997. Multiple effect evaporator throughput extension with unique chemistry. In: Tappi Pulping Conference, Tappi Press, (pp. 1041-1044).

Kumar, A., Badde, S., Kamble, R. and Pokharkar, V.B. 2010. Development and characterization of liposomal drug delivery system for nimesulide. Int. J. Pharm. Pharm. Sci., 4)2): 20-27.

Kumar, D., Kumar, V. and Singh, V. P. 2013. Modeling and dynamic simulation of mixed feed multi-effect evaporators in paper industry. Appl. Math. Model., 37(1-2): 384-397.

Matkar, A.D., Shelke, R.D. and Deshpande, H.N. 2017. Design and analysis of vertical evaporator refrigerator without freezer compartment. Int. J. Adv. Res. Dev., 21-7 :(10)2.

Morin, O.J. 1993. Design and operating comparison of MSF and MED systems. Desalination. 93(1-3): 69-109.

Rukade, S. K. and Bhosale, S. M. 2015. Applicability of evaporation and reverse osmosis techniques for volume reduction of textile mill effluent. Int. J. Sci. Res., 4(11): 2123-2127.

Salakki, S., Raj, L.A., Patil, J.H. and Shetty, V. 2014. Improving the efficiency of multiple effect evaporator to treat effluent from a pharmaceutical industry. Int. J. Innov. Res. Sci. Eng. Technol., 14731-14727:(7)3.

Sarma, G. and Barma, S. D. 2010. Energy management in multiple-effect evaporator system: A Heat Balance Analysis Approach. Gen. Math Notes, $88-84:(2) 1$.

Shah, D. J. and Bhagchandani, C. G. 2012. Design, modelling and simulation of multiple effect evaporators. Int. J. Sci. Eng. Technol., 5-1 :(3)1.

Vuppala, N. S., Suneetha, C. and Saritha, V. 2012. Study on treatment process of effluent in bulk drug industry. Int. J. Res. Pharm. Biomed. Sci., 1102-1095:(3)3.

Wade, N. M. 1993. Technical and economic evaluation of distillation and reverse osmosis desalination processes. Desalination, 93(1-3): 343-363.

Y1lmaz, İ.H. and Söylemez, M.S. 2012. Design and computer simulation on multi-effect evaporation seawater desalination system using hybrid renewable energy sources in Turkey. Desalination, 291: 23-40.

Zain, O. S. and Kumar, S. 1996. Simulation of a multiple effect evaporator for concentrating caustic soda solution - computational aspects. J. Chem. Eng. Jpn., 29(5): 889-893. 